\title{
AN INVESTIGATION INTO VOCABULARY LEARNING STRATEGIES EMPLOYED BY THE SECOND-YEAR NON-ENGLISH MAJOR STUDENTS AT THAI NGUYEN UNIVERSITY OF AGRICULTURE AND FORESTRY
}

\author{
Pham Thi Thu Trang \\ TNU University of Agriculture and Forestry
}

\section{ABSTRACT}

This study investigates on the most frequently used vocabulary learning strategies of the secondyear non-English major students at Thai Nguyen University of Agriculture and Forestry. The research method approach of the study was descriptive method and a questionnaire was used as the main data collection instrument. The major findings of the research showed that the students of Thai Nguyen University of Agriculture and Forestry employed a wide range of vocabulary learning strategies. Determination strategies were the most frequently used strategies while metacognitive strategies were preferred the least. It also revealed that students favored monolingual dictionaries, guessing from context and asking teachers or friends for meaning and concentrated mainly on the memorization of spoken form to consolidate the meaning of new word. Through these findings, some implications and recommendations are promisingly suggested for vocabulary learning.

Keywords: vocabulary learning strategies; non-English major students; Thai Nguyen University of Agriculture and Forestry; vocabulary learning.

Received: 11/4/2019; Revised: 13/5/2019; Approved: 15/5/2019

\section{NGHIÊN CÚU VIÊC SỬ DƯNG CÁC CHIẾN LƯỞC HOC TỬ VỰG CỦA SINH VIÊN NĂM THỨ HAI KHÔNG CHUYÊN TIẾNG ANH CỦA TRƯờnG ĐẠI HỌC NÔNG LÂM - ĐẠI HỌC THÁI NGUYÊN}

\author{
Phạm Thị Thu Trang \\ Trưòng Đại học Nông Lâm - ĐH Thái Nguyên
}

\section{TÓM TẮT}

Nghiên cứu này điều tra chiến lược học từ vựng được sử dụng thường xuyên nhất của sinh viên năm thứ hai không chuyên tiếng Anh tại trường Đại học Nông Lâm - Đại học Thái Nguyên. Phương pháp nghiên cứu được sử dụng là phương pháp thống kê mô tả với công cụ thu thập dữ liệu chính là bảng câu hỏi. Những phát hiện chính của nghiên cứu cho thấy sinh viên trường Đại học Nông Lâm - Đại học Thái Nguyên đã sử dụng nhiều chiến lược học từ vựng. Chiến lược xác định được sử dụng thường xuyên nhất trong khi các chiến lược siêu nhận thức được sử dụng ít nhất. Nó cũng chỉ ra rằng các sinh viên thích sử dụng từ điển đơn ngữ, đoán từ ngữ cảnh và hỏi giáo viên hoặc bạn bè để tìm hiểu ý nghĩa của từ và tập trung chủ yếu vào hình thức nói để củng cố nghĩa của từ mới. Thông qua những phát hiện này, một số đề xuất và ứng dụng được đưa ra phục vụ cho việc học từ vựng.

Từ khóa: chiến luợc học tù̀ vưng; sinh viên không chuyên tiếng Anh; Truờng Đại học Nông Lâm - Đại học Thái Nguyên; học tù̀ vựng.

Ngày nhận bài: 11/4/2019; Ngày hoàn thiện: 13/5/2019; Ngày duyệt đăng: 15/5/2019

Email: thutrang.pham90@gmail.com

DOI: https://doi.org/10.34238/tnu-jst.2019.06.591 


\section{Introduction}

In recent decades, vocabulary has been viewed as an important part of language study on which effective communication relies. Many researchers have stated that the mastery of vocabulary is a fundamental component in learning English. Schmitt [1], for example, believes that meaningful communication in a foreign language depends mostly on words. If learners do not have the available words to express their ideas, mastering grammatical rules does not help. A lot of the research also supports the idea that the more vocabulary words learners use, the greater learners' language learning success will be. Moreover, it is also an important factor for academic study. Many international academic tests of foreign language require a large amount of knowledge in vocabulary. Thus, it is without no doubt that vocabulary is the key to all the language skills; speaking, reading, writing and listening.

In Vietnam, the importance of vocabulary in second language acquisition has received great attention. For most university students, English vocabulary has long been their big headache on which they spend a lot of time. The teachers still mainly pay attention in explaining grammar and developing student's reading skills, leaving vocabulary to students themselves. Students, on the other hand, believe that learning a word is memorizing the spelling and the meaning of that word. Moreover, it is common to find that student's difficulties in both receptive and productive language use result from their insufficient vocabulary knowledge. It means that students yield a limited comprehension of the text in listening and reading or in speaking and writing students cannot use vocabulary productively. In order to bring a comprehensive picture of what the college students do with their English vocabulary learning, further research on this issue is needed. This study intends to investigate the vocabulary learning strategies that are mostly used by students.

\section{Subject and methodology}

The subjects of the study were second year non-English major students at Thai Nguyen University of Agriculture and Forestry. There were totally 100 students in two English classes participating in the research. In this study, quantitative data about students' vocabulary learning strategies according to their perspectives was collected through a questionnaire which provided a general picture of the research problem.

\section{Results and discussions}

\subsection{Use of overall strategies by the second year students at TUAF}

This section involved simple statistical methods used in order to analyse the data obtained from 100 TUAF students through the vocabulary learing strategy questionnaire. The frequency of strategy use was indicated on a five-point rating scale, ranging from "never", valued as 1; "rarely" valued as 2; "sometimes" valued as 3; "ususlly" valued as 4; "always" valued as 5. As a result, the average value of frequency of strategy use could be valed from 1.0 to 5.0. The mid-point of the minimum and the maximum values was 2.5. The mean frequency score of strategy use of each category or item valued from 1.0 to 2.4 was determined as "low use", from 2.5 to 3.4 as "medium use", and from 3.5 to 5.0 as "high use" [2].

According to table 1, the mean frequency score of students' reported strategy use ranged in varying degrees with moderate overall score. The usage levels of the five strategy categories were different and all their mean frequency fell within the range from 2.48 to 3.0. On average, the mean score of the participants' response was approximately 2.8 ; this meant that the research subjects reported employing vocabulary learning strategies with medium frequency when they had to deal with vocabulary learning. 
Table 1. The participants' responses to the use of the five strategy categories

\begin{tabular}{lcccc}
\hline Strategy category & M & SD & Frequency use & Rank order of the usage \\
\hline Determination & 3.00 & 1.009 & Medium use & 1 \\
Social & 2.48 & 0.954 & Low use & 5 \\
Memory & 2.81 & 1.009 & Medium use & 2 \\
Cognitive & 3.00 & 1.055 & Medium use & 4 \\
Metacognitive & 2.51 & 0.927 & Medium use & \\
Overall & 2.80 & 1.002 & Medium use & \\
\hline
\end{tabular}

\subsection{Use of each individual strategy by the second year students at TUAF}

\subsubsection{Determination strategies}

Table 2. Determination strategies: Means and Standard Deviations

\begin{tabular}{lcccc}
\hline & $\mathbf{N}$ & Mean & Std. Deviation & Strategy use \\
\hline Bilingual dictionary & 100 & 3.50 & 1.049 & $\mathrm{H}$ \\
Word lists & 100 & 3.39 & .815 & $\mathrm{M}$ \\
Guess the meaning from textual context & 100 & 3.32 & 1.034 & $\mathrm{M}$ \\
Analyze any available pictures or gestures & 100 & 3.09 & 1.111 & $\mathrm{M}$ \\
Analyze parts of speech & 100 & 2.99 & 1.059 & $\mathrm{M}$ \\
Analyze affixes and roots & 100 & 2.82 & .936 & $\mathrm{M}$ \\
Flash cards & 100 & 2.77 & .941 & $\mathrm{M}$ \\
Monolingual dictionaries & 99 & 2.17 & 1.134 & $\mathrm{~L}$ \\
\hline
\end{tabular}

It is apparently seen in table 2 that the most use strategy was bilingual dictionary with mean score of 3.5 ranked as high level of use. On the contrary, monolingual dictionary was reported at low frequency level $(\mathrm{M}=2.17$, $\mathrm{SD}=1.134)$. The rest were reported being employed at medium use. Among them guess the meaning from textual context and word lists also got more favor than the others with the mean score was 3.32 and 3.39 respectively.

The reason might be that using bilingual dictionary, word lists and guessing from the textual context often took time, monolingual dictionary, on the other hand, got the lowest attention from the student. In fact, the elementary students are often familiar with using bilingual dictionaries because it is convenient and easy for them to understand the meanings rather than taking time in monolingual dictionary. Research studies, moreover, showed that monolingual dictionary got more preferred by high achievers than low achievers. This strategy was very helpful for high level of learners especially for the English majors. This finding was similar to the results of Schmitt's [3] study among Japanese students who also favor the use of bilingual dictionary. It showed that bilingual dictionary was the most used strategies of all.

\subsubsection{Social strategies}

Social strategies, in general, seemed to get less prefer than the other strategies with only three strategies were ranked at medium use and the rest were low frequency. As shown in table 3, social strategies were not frequently used by the students. Asking teachers or friends for L1 translation was the most frequently used strategy while interacting with native speakers was the least frequently used. This fact can be easily understood because students were not afraid to ask their friends or teachers for their help in L1 translation. The students, on the other hand, did want to interact with native speakers although they did not have many chances. That was the objective reason why few of them employed the strategy of interacting with native speakers. 
Table 3. Social strategies: Means and Standard Deviations

\begin{tabular}{|c|c|c|c|c|}
\hline & $\mathbf{N}$ & Mean & Std. Deviation & Strategy use \\
\hline Ask classmates for meaning & 99 & 3.12 & .982 & $\mathrm{M}$ \\
\hline Ask teacher for an L1 translation & 100 & 2.93 & .946 & M \\
\hline $\begin{array}{l}\text { Ask teacher for paraphrase or synonym } \\
\text { of a new word }\end{array}$ & 100 & 2.67 & .943 & M \\
\hline Study and practice meaning in a group & 100 & 2.45 & .978 & $\mathrm{~L}$ \\
\hline $\begin{array}{l}\text { Ask teacher for a sentence including the } \\
\text { new word }\end{array}$ & 100 & 2.41 & .944 & $\mathrm{~L}$ \\
\hline $\begin{array}{l}\text { Teacher checks students' flash cards or } \\
\text { word lists for accuracy }\end{array}$ & 100 & 2.33 & .933 & $\mathrm{~L}$ \\
\hline $\begin{array}{l}\text { Discover new meaning through group } \\
\text { work activities }\end{array}$ & 100 & 2.21 & .946 & $\mathrm{~L}$ \\
\hline Interact with native speaker & 100 & 1.79 & .967 & $\mathrm{~L}$ \\
\hline
\end{tabular}

3.2.3. Memory strategies

Table 4. Memory strategies: Means and Standard Deviations

\begin{tabular}{lcccc}
\hline & N & Mean & Std. Deviation & Strategy use \\
\hline Say new word aloud when studying & 100 & 3.49 & 1.000 & $\mathrm{M}$ \\
Study the sound of a word & 100 & 3.38 & .896 & $\mathrm{M}$ \\
Image word form & 100 & 3.11 & 1.063 & $\mathrm{M}$ \\
Image word's meaning & 100 & 3.06 & .886 & $\mathrm{M}$ \\
Affixes and roots (remembering) & 100 & 3.05 & .999 & $\mathrm{M}$ \\
Part of speech (remembering) & 100 & 3.05 & 1.009 & $\mathrm{M}$ \\
Associate the word with its synonyms and & 100 & 3.03 & .926 & $\mathrm{M}$ \\
antonyms & 100 & 2.91 & 1.055 & $\mathrm{M}$ \\
Paraphrase the word's meaning & 100 & 2.87 & .991 & $\mathrm{M}$ \\
Study the spelling of a word & 100 & 2.86 & 1.110 & $\mathrm{M}$ \\
Use keyword method & 100 & 2.85 & .936 & $\mathrm{M}$ \\
Use new word in sentences & 100 & 2.85 & 1.123 & $\mathrm{M}$ \\
Group words together to study them & 100 & 2.84 & 1.002 & $\mathrm{M}$ \\
Associate the word with its coordinates & 100 & 2.80 & 1.015 & $\mathrm{M}$ \\
Learn the words of an idiom together & 100 & 2.79 & .957 & $\mathrm{M}$ \\
Study word with a pictorial presentation of & & & $\mathrm{M}$ \\
its meaning & 100 & 2.74 & 1.060 & $\mathrm{M}$ \\
Connect word to a personal experience & 100 & 2.53 & 1.049 & $\mathrm{~L}$ \\
Use physical action when learning a word & 100 & 2.35 & 1.114 & $\mathrm{~L}$ \\
Underline initial letter of the word & 100 & 2.32 & 1.014 & $\mathrm{~L}$ \\
Use 'scales' for gradable adjectives & 100 & 2.15 & 1.067 & $\mathrm{~L}$ \\
Group words together within a storyline & 100 & 2.01 & .937 & $\mathrm{H}$ \\
Use semantic maps &
\end{tabular}

It can be seen in table 4 that most of the strategies employed to consolidate the word in the memory were used at medium level (mean score from 2.53 to 3.49). No high use of VLS by these students in order to retain the knowledge of newly-learned vocabulary items. Seventeen VLS in this category were reported being employed at medium frequency level, whereas four VLS were reported at the low frequency level. It is implied that besides using strategies to discover a word's meaning, the learners also used some strategies to consolidate it in memory. 
Table 5. Cognitive strategies: Means and Standard Deviations

\begin{tabular}{lcccc}
\hline & N & Mean & Std. Deviation & Strategy use \\
\hline Take note in class & 100 & 3.93 & .935 & $\mathrm{H}$ \\
Verbal repetition & 100 & 3.40 & .995 & $\mathrm{M}$ \\
Written repetition & 100 & 3.36 & .980 & $\mathrm{M}$ \\
Use the vocabulary section in your & 100 & 3.22 & 1.011 & $\mathrm{M}$ \\
textbook & 100 & 2.97 & 1.235 & $\mathrm{M}$ \\
Keep a vocabulary notebook & 100 & 2.72 & .965 & $\mathrm{M}$ \\
Listen to tape of word lists & 100 & 2.64 & 1.020 & $\mathrm{M}$ \\
Word lists & 100 & 2.51 & 1.193 & $\mathrm{M}$ \\
Flashcards & 100 & 2.26 & 1.169 & $\mathrm{~L}$ \\
Put English labels on physical objects &
\end{tabular}

Table 6. Metacognitive strategies: Means and Standard Deviations

\begin{tabular}{lcccc}
\hline & N & Mean & Std. Deviation & Strategy use \\
\hline Use English-language media (songs, & 100 & 3.05 & .947 & M \\
movies, newscasts, etc.) & 100 & 2.65 & .903 & $\mathrm{M}$ \\
Continue to study word over time & 100 & 2.46 & 1.049 & $\mathrm{~L}$ \\
Testing oneself with word tests & 100 & 1.90 & .810 & $\mathrm{~L}$ \\
Skip or pass new word & & sur
\end{tabular}

\subsubsection{Cognitive strategies}

The information in table 5, in general, showed that cognitive strategies were used at medium level. Only taking note in class was selected as the highest frequency use with mean score was 3.93 and the lowest mean score was put English labels on physical objects with $\mathrm{M}=2.26$.

Cognitive strategies were preferred by the students when every strategy was used at medium level. The most strategies use were taking note in class, verbal and written repetition, studying the vocabulary in the textbook, keeping a vocabulary notebook. These are very simple and feasible activities for the students, so that they should be encouraged to use them as often as a habit.

\subsubsection{Metacognitive strategies}

Four metacognitive strategies in consolidating words were shown in table 6 with two medium use strategies and two low use strategies.

In a whole, metacognitive strategies were not frequently used. Mean values of this group ranged from 1.90 to 3.05. Most of the students used television, radio, newspapers, magazines, computers, etc. with quite high frequency. The public internet has become more popular, so that students should make use of this kind of modern technology for the purpose of learning English in general and for learning English vocabulary in particular. It was hoped that there would be a large proportion of the students continuing to study words overtime or study words every day with high frequency; however, a small number of them always did this. Teachers should know this and think of ways to encourage, even request their students to employ this strategy.

\section{Conclusions and recommendations}

\subsection{Conclusion}

The findings from the study proved that second year students of English at TUAF were medium strategies users. Among the strategies used to discovery and consolidate the meaning of new word, the students used determination strategies most frequently while metacognitive strategies were used least frequently. Among fifty strategies, most of the students used these strategies in the 
medium level; about one fourth of them used those ones in the low level, and only two items (Use bilingual dictionary and Take notes in class) was in the high level. These strategies, on the other hand, were considered to be simple and support for individual learning. Thus, some practical suggestions would be made to help students learn vocabulary more effectively.

\subsection{Recommendations}

Firstly, some other aspects which should be further explored include students' socioeconomic or academic backgrounds, or attitude and motivation towards vocabulary learning.

Secondly, there should be a greater variety of instruments produced to elicit students' VLS of different language learners in different contexts.

Thirdly, there is a need for future research to investigate a larger research population consists of students studying in different years $\left(1^{\text {st }}, 2^{\text {nd }}, 3^{\text {rd }}, 4^{\text {th }}\right)$ to explore if this aspect associates with students' reported choices of strategy use for vocabulary learning.

Finally, the present study only concentrated on the current situation of vocabulary learning and did not take into account the fact that learning strategy use changes over time when the learner's skills develop and mature. Thus, a longitudinal study of vocabulary learning strategies training long-term effects should be considered.

\section{REFERENCES}

[1]. Schmitt, N., Researching vocabulary: A vocabulary research manual, London, England: Palgrave Macmillan, 2010.

[2]. Oxford, R. L., Language learning strategies: What every teacher should know, New York: Newbury House, 1990.

[3]. Schmitt, N., "Vocabulary learning strategies", In N. Schmitt and M. McCarthy (Eds), Vocabulary: description, acquisition and pedagogy (pp. 237-257). Cambridge: Cambridge University Press, 1997. 